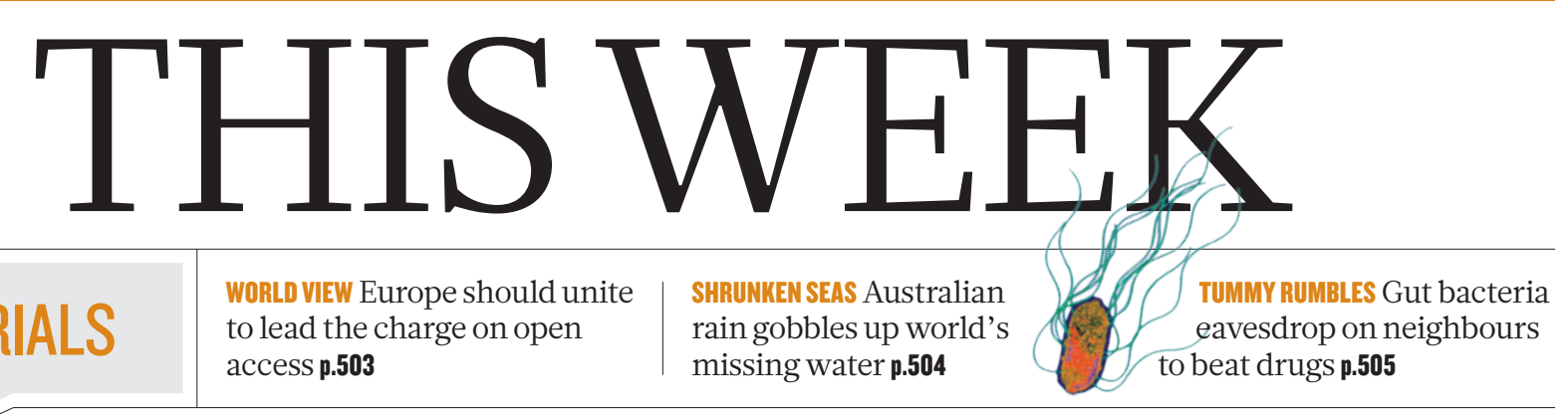

EDITORIALS access $\mathbf{p . 5 0 3}$

\title{
Hidden heat
}

\section{Scientists are homing in on the reasons for the current hiatus in global warming, but all must recognize that the long-term risk of warming from carbon dioxide remains high.}

$\mathrm{T}$ This week, Nature publishes a study online suggesting that a recent cooling trend in the tropical Pacific Ocean can explain the current hiatus in global warming. Authored by a pair of scientists at the Scripps Institution of Oceanography in La Jolla, California, the paper does not say why the Pacific seems to have entered a prolonged 'La Niña' phase, in which cooler surface waters gather in the eastern equatorial Pacific. It is also silent on where the missing heat is going. But it does suggest that this phenomenon - affecting as little as $8 \%$ of Earth's surface - could temporarily counteract the temperature increase expected from rising greenhouse-gas emissions (Y. Kosaka and S.-P. Xie Nature http://dx.doi.org/10.1038/nature12534; 2013).

Previous modelling studies have linked the pause to La-Niña-like conditions that have prevailed since 1999, suggesting that heat that would otherwise go into the atmosphere is getting buried deeper in the ocean. And scientists at the National Center for Atmospheric Research in Boulder, Colorado, have a study in the press indicating that decades in which global air temperature rises rapidly — including the 1980s and 1990s - are associated with warmer temperatures in the tropical Pacific, as exemplified by La Niña’s opposite effect, El Niño (G. A. Meehl et al. J. Climate http://doi.org/nkw; 2013). The Scripps researchers also confirmed that El-Niño-like conditions can boost global temperatures.

Scientists seem to be homing in on an important lever in the climate system. And none too soon. Although a prolonged hiatus in warming does not necessarily contradict prevailing theory, this one came as a surprise and has been used to discredit the climate-science community. The story will probably not end there. Scientists know that the Sun has been in a prolonged solar minimum for several years, which means less incoming energy, and there may yet be a role for sunlight-blocking aerosols - human pollution and volcanic ash - and other factors in the hiatus. But at least a better explanation of the climate system is beginning to take shape.

All of this comes as the Intergovernmental Panel on Climate Change (IPCC) prepares to release the first instalment of its fifth assessment report. The hiatus in warming is at the centre of an ongoing debate about 'equilibrium climate sensitivity', which is the amount of warming that would be expected over the long term owing to a doubling of atmospheric carbon dioxide levels. Several papers have assessed the most recent data and conclude that the climate may not be as sensitive to greenhouse gases as was previously thought. The latest draft of the IPCC summary for policy-makers accounts for this - just. It suggests a likely climate sensitivity of $1.5-4.5^{\circ} \mathrm{C}$, compared with a range of $2-4.5^{\circ} \mathrm{C}$ in the IPCC's last assessment report.

Some argue that recent temperature trends show that the climate problem is less urgent. One can only hope that this is so, and scientists will continue to probe the matter. But policy-makers would be foolhardy to think that the danger has receded. Although scientists understand the basic physics, nobody can know how the numbers will turn out, as shown by the various temperature projections. Plenty of other lines of evidence, including palaeoclimate data and modern modelling experiments, support the higher end of these.

Ultimately, the decision over how to characterize climate sensitivity will fall to government officials who will approve - under the watchful eye of scientists - the latest IPCC documents in Stockholm next month. Whatever their decision, the underlying science has not changed..

\section{Beyond compare}

\section{Metaphors are like cheese - often desirable but sometimes full of holes.}

$\mathrm{I}$ $\mathrm{n}$ an Amazon review of the 2013 book Creation, written by former Nature editor Adam Rutherford, one critic takes issue with what he describes as the work's "wordy trickery" "I lost count," the reviewer complains, "of the number of times that an obscure word or metaphor was helicoptered in."

Supplied by airlift or not, the online grumble illustrates both the irritation that some feel at analogies and metaphor in scientific writing, as well as the ease with which they can be, ahem, helicoptered in. It's a debate as old as, well, the hills. And one revived in a Comment article on page 523 that fizzes with... [That's enough metaphors - Ed.].

In the piece, Eleonore Pauwels, a public-policy researcher in the Science and Technology Innovation Program at the Woodrow Wilson International Center for Scholars in Washington DC, argues that biologists confuse the public when they borrow terms from engineering. Turning on genetic switches and assembling molecular components are processes that are more complex and ill-defined than the imagery might suggest, she says.

Metaphors, writers insist, breathe life into scientific language. But that is the problem, others say. The tendency to anthropomorphize the natural world was dubbed the "pathetic fallacy" by the nineteenthcentury art critic John Ruskin. He would have hated the selfish gene.

Still, metaphor has a legitimate place in science. The idea that electrons orbit the nucleus like planets go around the Sun sets up testable hypotheses. Perhaps the problems come when scientific metaphors seek points for artistry rather than aiming for the quiet satisfaction of a job well done.

The English poet John Donne (1572-1631) famously compared the bound souls of lovers to a pair of compasses. "If they be two, they are two so / As stiff twin compasses are two." To compare a pair of compasses to the souls of lovers, however, would be wordy trickery too far. 